\title{
RESEARCH PAPER \\ Role of flower preservative solutions during postharvest of Hydrangea macrophylla cv. Bela
}

\author{
Danilo Aros ${ }^{1}$, Cristian Silva ${ }^{1}$, Cielo Char ${ }^{1}$, Loreto Prat ${ }^{1}$, and Víctor \\ Escalona $^{1,2}$ \\ ${ }^{1}$ Universidad de Chile, Facultad de Ciencias Agronómicas. Santa Rosa 11315, La Pintana, Santiago, Chile. \\ ${ }^{2}$ Centro de Estudios Postcosecha, Universidad de Chile, Santiago, Chile.
}

\begin{abstract}
D. Aros, C. Silva, C. Char, L. Prat, and V. Escalona. 2016. Role of flower preservative solutions during postharvest of Hydrangea macrophylla cv. Bela. Cien. Inv. Agr. 43(3):418428. Hydrangea macrophylla (hydrangea) is widely used as an ornamental plant and cut flower due to its inflorescence, which is composed of colored bracts. As cut flowers, hydrangeas show a postharvest life of up to 1 month at $2{ }^{\circ} \mathrm{C}$, but little is known about their postharvest life during air shipment. This study was aimed at evaluating the effect of Triton X-100 (surfactant) and $\mathrm{ClO}_{2}$ (biocide) during an air shipment simulation of hydrangea harvested at two floral stages of development: fresh and antique. Vase life, fresh weight loss (FWL) and solution uptake were evaluated after an air shipment simulation. Furthermore, bacterial counts and microscopic observation of the bracts were performed in order to understand the water relations of hydrangea during vase life. The longest vase life was observed in antique hydrangeas, and the control (deionized water) was the best treatment, reaching up to 32.7 days in this floral stage. FWL was faster when using Triton X-100 (3.83 days to lose $20 \%$ of FW) compared to deionized water ( 8.75 days). However, this flower preservative was efficient at promoting solution uptake $(31.96 \mathrm{~mL})$. Bacterial plugging did not appear to occur considering that the high presence of microorganisms counted did not affect solution uptake or vase life. The presence of stomata on the bracts seems to be crucial for the dehydration of the inflorescence, a problem that was not solved by the higher water uptake promoted by Triton X-100. Thus, deionized water was the best treatment, and the effect of flower preservatives in order to extend vase life of hydrangea cut flowers was insignificant.
\end{abstract}

Key words: $\mathrm{ClO}_{2}$, hydrangea, Triton $\mathrm{X}-100$, vase life

\section{Introduction}

Hydrangea macrophylla (hydrangea) is a deciduous shrub native to eastern Asia widely used as an ornamental plant in gardens and as cut flow-

Received June 07, 2016. Accepted October 5, 2016 Corresponding author: daros@uchile.cl ers (Sacco et al., 2012). Hydrangeas are popular for their colorful, sphere-shaped inflorescence, which is highly demanded at Christmas and Mother's Day, mostly by the European and North American markets (van Gelderen and van Gelderen, 2004). H. macrophylla inflorescences are composed of several partial inflorescences, which are composed of small fertile florets and sterile 
florets with large colored bracts. The decorative value of hydrangeas comes from these colored bracts, which probably arose as a mutation or arrest of certain genes involved in floral organ morphogenesis. As cut flowers, hydrangeas are harvested at three different stages according to the development of the color of the bracts: fresh, transition and antique (Schiappacasse et al., 2014). Hydrangea cut flowers show a postharvest life of up to 1 month at $2{ }^{\circ} \mathrm{C}$, but this period is shorter if hydrangeas are stored or transported at higher and variable temperatures (Dole and Wilkins, 1999).

The postharvest life of cut flowers depends on several biotic and abiotic factors that induce the senescence of different plant organs. Thus, control of temperature, relative humidity, light, ethylene, microorganisms, water quality, and others factors are all important to maintaining the quality of cut flowers during their postharvest life. Temperature is the most important factor since high temperature triggers an increase in the respiration rate, causing rapid senescence of the flower (Kader, 2007). Relative humidity (RH) is also important because it plays a key role in the dehydration of cut flowers, one of the main deteriorating symptoms observed during postharvest.

Flower preservative solutions, with both surfactant and antimicrobial effects, are usually used to prolong the vase life of cut flowers, particularly in cases where flowers cannot be kept at low temperatures during storage and transportation. Surfactants help to quickly rehydrate flowers because a reduction of the surface tension of water improves water uptake (Seyed et al., 2012). Chemical preservatives with surfactant effects include 8-hydroxyquinoline citrate, 8-hydroxyquinoline sulfate, alkylethoxylate (van Doorn et al., 2001), Tween-20, Tween-80, Agral-LN (van Doorn et al., 2001), and Triton X-100 (Jones et al, 1993), among others. Those with biocidal effects help to prevent occlusions from occurring mainly at the basal stem end of cut flowers, which strongly decrease water uptake from the vase, and many products have been used in cut flowers for this purpose such as sodium hypochlorite (Macnish et al., 2010), silver nitrate (Figueroa et al., 2005), Physan 20, 8-hydroxyquinoline (Cruz et al., 2006), silver thiosulfate (Figueroa et al., 2005) and chlorine dioxide (Macnish et al., 2008). Despite the benefits described for these flower preservatives, their effects depend on the dosage and duration of exposure (Chao et al., 2010; Macnish et al., 2008), since in certain species, high doses or long exposure may provoke toxicity and thereby reduce vase life by dehydration, browning (van Doorn et al., 2001), leaf chlorosis and premature flower drop (Macnish et al., 2008).

Studies focused on hydrangea postharvest have shown that this species lasts for 7 to 9 days after storage for 20 days at $0.5^{\circ} \mathrm{C}$ (Schiappacasse et al., 2014). Moreover, vase solution with an electrical conductivity (EC) between 2.0 and $2.5 \mathrm{dS} \mathrm{m}^{-1}$ and a $\mathrm{pH}$ of 3.2 has been described as optimal to extend the vase life of hydrangea (Ahmad et al., 2013). However, the effect of flower preservatives during hydrangea postharvest has not been studied. Furthermore, studies focused on evaluating the postharvest of this species after the variable conditions occurring during air shipment, the main transportation mode for this species, have not been considered. Hence, this study was aimed at evaluating the effect of the biocide chlorine dioxide $\left(\mathrm{ClO}_{2}\right)$ and the surfactant octyl phenol ethoxylate (Triton X-100) on the postharvest life of cut flowers of hydrangea, simulating air shipment conditions from harvest to final market.

\section{Materials and methods}

\section{Plant material}

Flowers of H. macrophylla cv. Bela were harvested from 3-year-old plants grown under open-air conditions covered only by a shading net. Stems were cut $30 \mathrm{~cm}$ in length in order to obtain uniform quality, and bunches were arranged according to the treatments described below. The blades used to harvest were surface sterilized in $95 \%(\mathrm{v} / \mathrm{v})$ 
ethanol prior to use. Harvesting was performed during the morning in the middle of February at a farm located in Pirque, Region Metropolitana, Chile. Harvested stems were placed for $20 \mathrm{~h}$ at 22 ${ }^{\circ} \mathrm{C}$ for rehydration. To assess the effect of floral development at harvest time during postharvest of hydrangea, two floral stages were evaluated: fresh and antique.

\section{Treatments}

Floral preservative solutions were used both during air shipment simulation experiments and during the vase life evaluations. The treatments were as follows: deionized water, Triton X-100, $\mathrm{ClO}_{2}$ and $\mathrm{ClO}_{2}+$ Triton X-100 for each floral stage. To simulate the air shipment conditions normally used by Chilean export companies to send cut flowers overseas, each floral stem was put into a $20 \mathrm{~mL}$ Aquapick ${ }^{\circledR}$ tube containing the preservative solution, and different storage conditions were used at each of the five stages of the export process: 0 . Harvest and ground transport to the airport; 1. Waiting for inspection and shipment at the airport (20 h); 2. Loading of the flowers into the airplane $(3 \mathrm{~h}) ; 3$. Storage of the flowers during the flight from Santiago in Chile to Miami in the USA (10 h); and, 4 . Storage at destination before customer consumption (64 h) (Table 1).

\section{Flower preservative solutions}

The biocide chlorine dioxide $\left(\mathrm{ClO}_{2}\right)$ (Difem Pharma, Santiago, Chile) was used at a concentration of 2 $\mu \mathrm{L} \times \mathrm{L}^{-1}$ with or without the addition of $0.1 \mathrm{~mL} \times \mathrm{L}^{-1}$ of the surfactant octyl phenol ethoxylate (Triton X-100) (Calbiochem, USA). Deionized water was used to make the preservative solutions.

\section{Vase life evaluation}

After the air shipment simulation, the flowers were placed in $1.5 \mathrm{~L}$-plastic vases at ambient conditions $\left(20{ }^{\circ} \mathrm{C} \pm 2{ }^{\circ} \mathrm{C}, 60 \pm 5 \%\right.$ relative humidity and a $12 \mathrm{~h}$ photoperiod). Each vase, containing 3 floral stems, was filled with $1 \mathrm{~L}$ of preservative solution. The open end of the vase was sealed around the stems with Parafilm. Vase life was evaluated daily according to a sensorial scale considering the quality of bracts (dehydration and inward rolling) and inflorescences (browning). The scale was developed based on previous studies, and scores ranged from 1 to 5 (Table 2). The end of vase life was considered the day when the average score of the treatment was $\leq 3$. Additionally, photographs of each treatment were recorded using a Nikon D3000 10 Mpx Black (Nikon Co., Tokyo, Japan). The daily amount of vase solution taken by the hydrangeas was estimated by weighing the vases and floral stems separately every day, and the results were subtracted and expressed in $\mathrm{mL}$. To monitor the fresh weight evolution of the floral stems, they were weighed daily and individually, and the values were expressed as a percentage of the initial fresh weight. Considering that all the treatments showed different vase life (days), this parameter was evaluated as the number of days when floral stems reached $20 \%$ of fresh weight loss, which is considered critical for some cut flowers (Kader, 2007).

\section{Microbiological analyses}

Microbial counts in the preservative solution at the end of the flight simulation period were performed by collecting a sample from the Aquapick ${ }^{\circledR}$ tube and during vase life by collecting a sample from the vase solution. In both cases, a 6-mL sample composed of $2 \mathrm{~mL}$ from each of the replicates of each treatment was evaluated. Samples were placed into sterile bags for blending in a Stomacher ${ }^{\circledR} 400$ Circulator (Seward, Worthing, UK) for $1 \mathrm{~min}$. Each sample was diluted in $54 \mathrm{~mL}$ of peptone water and then placed in a Masticator Classic (IUL Instruments, Barcelona, Spain) for homogenization for $1 \mathrm{~min}$. Serial dilutions from $10^{-1}$ to $10^{-8}$ were prepared and plated on Plate Count Agar for $48 \mathrm{~h}$ at $37{ }^{\circ} \mathrm{C}$. Additionally, a 
Table 1. Simulation of the export conditions of cut hydrangea flowers from Santiago (Chile) to Miami (USA), according to information provided by Chilfresh Ltda. (flower exporter).

\begin{tabular}{lccccc}
\hline & & \multicolumn{2}{c}{ External } & \multicolumn{2}{c}{ Internal } \\
Stage & Duration $(\mathrm{h})$ & $\mathrm{T}\left({ }^{\circ} \mathrm{C}\right)$ & $\mathrm{RH}(\%)$ & $\mathrm{T}\left({ }^{\circ} \mathrm{C}\right)$ & $\mathrm{RH}(\%)$ \\
\hline 0 & 28 & 22.0 & 60.7 & 22.5 & 59.1 \\
1 & 20 & 13.6 & 75.2 & 16.1 & 72.6 \\
2 & 3 & 31.1 & 46.7 & 22.2 & 78.8 \\
3 & 10 & 13.3 & 86.6 & 15.4 & 75.0 \\
4 & 64 & 5.2 & 93.3 & 5.8 & 83.7 \\
\hline
\end{tabular}

Table 2. Sensorial scale for vase life evolution of Hydrangea macrophylla cv. cut flowers based on parameters related to bracts and inflorescences.

\begin{tabular}{|c|c|c|}
\hline \multirow[b]{2}{*}{ Score } & \multicolumn{2}{|c|}{ Parameter } \\
\hline & Characteristics of bracts & Browning of inflorescences (\%) \\
\hline \multirow{2}{*}{5} & 100 to $95 \%$ turgid bracts & \multirow{2}{*}{0 to 2} \\
\hline & 0 to $5 \%$ bract in-rolling & \\
\hline \multirow{2}{*}{4} & 95 to $70 \%$ turgid bracts & \multirow{2}{*}{2 to 4} \\
\hline & 5 to $15 \%$ bract in-rolling & \\
\hline \multirow{2}{*}{3} & 70 to $50 \%$ turgid bracts & \multirow{2}{*}{4 to 6} \\
\hline & 15 to $50 \%$ bract in-rolling & \\
\hline \multirow{2}{*}{2} & 50 to $10 \%$ turgid bracts & \multirow{2}{*}{6 to 8} \\
\hline & 50 to $80 \%$ bract in-rolling & \\
\hline \multirow{2}{*}{1} & 10 to $0 \%$ turgid bracts & \multirow{2}{*}{8 a 10} \\
\hline & 80 to $100 \%$ bract in-rolling & \\
\hline
\end{tabular}

$10 \mathrm{~g}$ sample from the base of the stem was also collected to count the microbes accumulated in the plant tissue. The samples were placed into sterile bags with $100 \mathrm{~mL}$ of peptone water for homogenization for $1 \mathrm{~min}$. Serial dilutions and plates were performed under the same conditions previously described.

\section{Microscopic observation of bracts}

Stomata counts on the bracts of the flowers were performed by direct observation of the epidermis under a CX21FS1 Olympus stereoscopic microscope (Olympus, Tokyo, Japan). Epidermal tissue was obtained by directly stripping off the epidermal layer from both sides (abaxial and adaxial) of the bracts using tweezers. Fresh epidermal tissue was stained with toluylene red and observed using $40 \mathrm{X}$ magnification. Stomatal density was expressed as the number of stomata per $\mathrm{mm}^{-2}$ of epidermal tissue.

\section{Experimental design and statistical analyses}

A completely randomized design with factorial arrangement was used. Data on flower fresh weight loss, vase life and preservative solution uptake from the vase were subjected to an analysis of variance (ANOVA) using INFOSTAT software (Infostat, 2002). Means were compared using Tukey's HSD (honestly significant difference) test for multiple pairwise comparisons with a 5\% significance level. 


\section{Results}

\section{Vase life evaluation}

The vase life of hydrangea flowers was assessed according to the quality of bracts and inflorescences. Statistical analysis showed no interaction between 'floral stage' and 'vase solution', therefore they were independently analyzed using ANOVA. Surprisingly, the longest vase life was reached by using deionized water, showing significant differences from the rest of the treatments in the antique stage (32.7 days). For the fresh stage, deionized water alone or combined with $\mathrm{ClO}_{2}$ reached the longest vase life (17.7 days), which was significantly longer than the rest of the treatments (Figure 1; Table 3).

Fresh weight loss and solution uptake of cut hydrangea flowers

Weight loss was measured during vase life and expressed as the number of days to lose $20 \%$ of

Table 3. Vase life (days) of Hydrangea macrophylla cv. Bela cut flowers at $20^{\circ} \mathrm{C}$ and $50 \% \mathrm{RH}$ after a flight trip simulation period using flower preservative solutions based on combinations of deionized water, $\mathrm{ClO}_{2}$ and Triton X-100.

\begin{tabular}{lcccc}
\hline & \multicolumn{4}{c}{ Flower preservative solution } \\
\cline { 2 - 5 } Floral stage & Deionized water & $\mathrm{ClO}_{2}$ & Triton X-100 & Triton X-100 + ClO \\
\hline Fresh & $\mathrm{A}^{1} 17.67 \mathrm{a}^{2}$ & $\mathrm{~A} 17.67 \mathrm{a}$ & $\mathrm{B} 8.33 \mathrm{a}$ & $\mathrm{B} 8.00 \mathrm{a}$ \\
Antique & A $32.70 \mathrm{~b}$ & B $23.33 \mathrm{~b}$ & $\mathrm{C} 14.00 \mathrm{~b}$ & $\mathrm{D} 9.33 \mathrm{~b}$ \\
\hline
\end{tabular}

${ }^{1}$ Different capital letters in a row indicate significant differences according to Tukey's test $(\mathrm{P} \leq 0.05)$.

${ }^{2}$ Different small letters in a column indicate significant differences according to Tukey's test $(\mathrm{P} \leq 0.05)$.

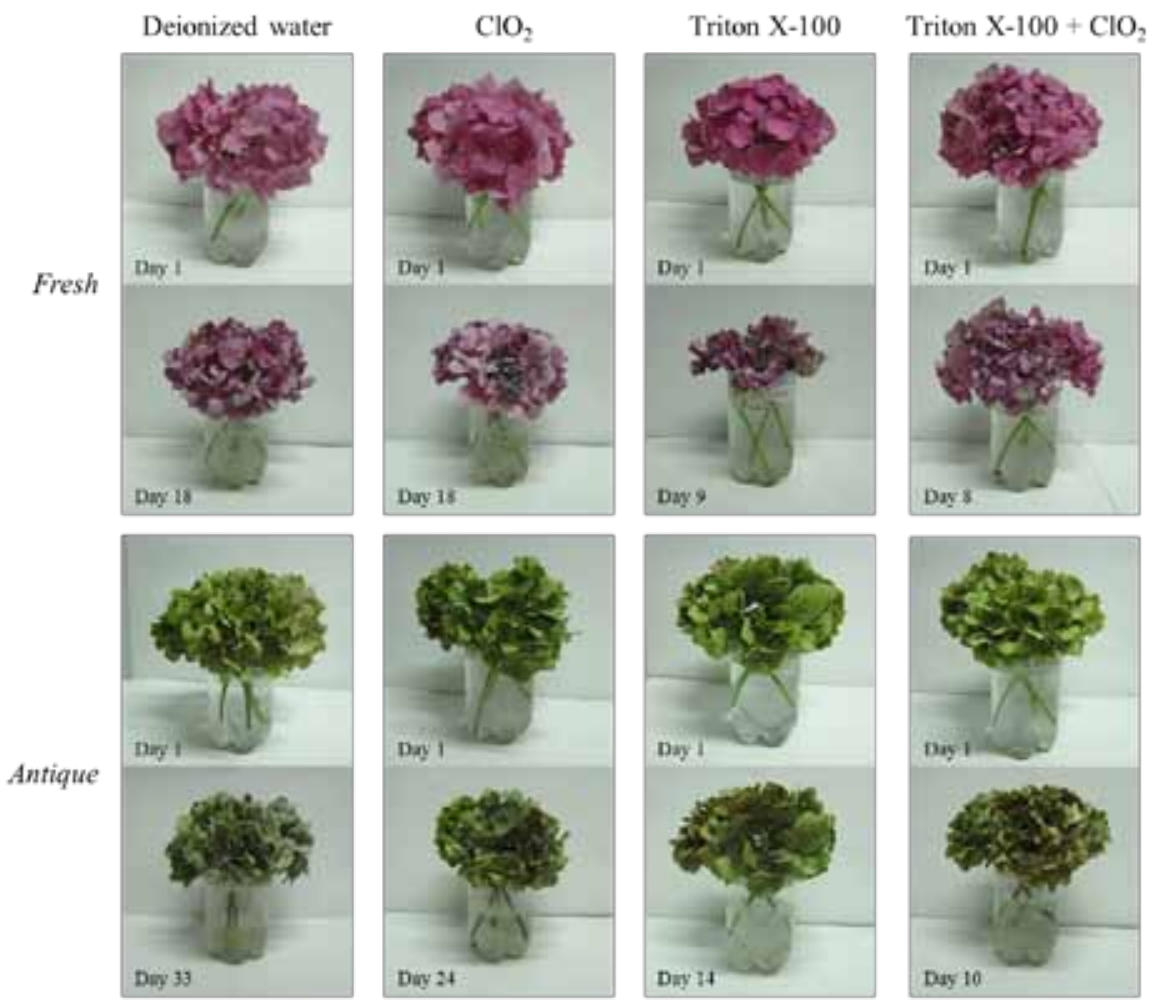

Figure 1. Development of Hydrangea macrophylla cv. Bela cut flowers from the beginning until the end of vase life, using flower preservative solutions based on combinations of deionized water, $\mathrm{ClO}_{2}$ and Triton X-100. 
the cut flower fresh weight. All treatments showed significant fresh weight loss (FWL) until day five when, due to vase solution uptake, all the flowers recovered their initial fresh weight. The slowest FWL was observed in the treatment using deionized water with an average of 8.75 days, and it was significantly different from the treatment using Triton X-100, which lost $20 \%$ of fresh weight at day 3.83. Although not significantly different from deionized water, $\mathrm{ClO}_{2}$ and Triton X-100+ $\mathrm{ClO}_{2}$ reached $20 \%$ flower $\mathrm{FWL}$ faster, with 7.50 and 6.83 days, respectively (Table 4).

Solution uptake was evaluated daily, and a comparison among treatments was performed on the day when the flowers reached $20 \%$ FWL. The highest solution uptake was observed using Triton X-100 $(31.96 \mathrm{~mL})$, and it was significantly different from the control. The treatments using $\mathrm{ClO}_{2}$ and Triton $\mathrm{X}-100+\mathrm{ClO}_{2}$ were not different from the control, taking up 26.56 and $26.44 \mathrm{~mL}$, respectively (Table 4).

\section{Bacterial count}

Treatments using both chlorine dioxide and Triton $\mathrm{X}-100$ were more effective at delaying microbial growth, showing the lowest count of bacteria in the Aquapick ( $\left.4.3 \log \mathrm{CFU} \mathrm{mL} \mathrm{mL}^{-1}\right)$ and at the base of the stems (5.1 $\left.\log \mathrm{CFU} \mathrm{g}{ }^{-1}\right)$. Aquapick showed the lowest count of bacteria (between 4.3 and $6.1 \log \mathrm{CFU} \mathrm{mL} \mathrm{m}^{-1}$ ), probably due to the shorter period of time (5.2 days) that the flowers were kept under this condition (Table 1) compared to the vase solution (ranging between 5.9 and 7.0 $\log \mathrm{CFU} \mathrm{mL} \mathrm{m}^{-1}$ ), where the flowers were kept for more than 8 days during the vase life (Figure 2).

\section{Discussion}

Vase life is affected by both floral stage and vase solution

The antique floral stage showed the longest vase life, significantly longer than that of fresh for all the flower preservative solution treatments applied (Table 3). van Doorn and Han (2011) observed longer vase life in lilies harvested at more mature stages, suggesting that postharvest is related to the accumulation of carbohydrates in the tepals. Thus, the hydrangeas in the antique stage may have higher levels of carbohydrates to redistribute and extend the vase life of this species.

Regarding the use of deionized water, van Meeteren and van Gelder (1999) observed better results using tap water during the vase life of chrysanthemum, suggesting that low concentrations of several ions present in this water positively affect the water balance of this species. The treatment using $\mathrm{ClO}_{2}$ and Triton X-100 together showed the shortest vase life, and the main factor determining the end of vase life observed was browning of inflorescences, suggesting signs of toxicity provoked by the absorption of these preservative solutions (Figure 1).

Although previous studies have reported good results using surfactants in rose and sunflower for vase life (Jones et al., 1993), they are sometimes associated with negative effects, such as leaf yellowing, pedicel bending and chlorosis, particularly with concentrations higher than $300 \mathrm{mg} \mathrm{L}^{-1}$ (van Doorn et al., 2002). Furthermore, Hajizadeh et al. (2012) found lower levels of anthocyanin in roses treated with the surfactants 8 -HQC and silver nitrate during postharvest. Anthocyanins are responsible for the color in hydrangeas, and their degradation, which was observed in fresh hydrangeas (Figure 1), could have been accelerated by the effect of the surfactants applied.

Chlorine dioxide produces an oxidizing effect on organic molecules of the cell, causing disruption of various cellular processes, and it has been described to have low toxicity in comparison with other biocides (Koermer and Wldman, 2002). On the other hand, Macnish et al. (2008) recommended $2 \mu \mathrm{L} \mathrm{L}^{-1}$ of $\mathrm{ClO}_{2}$ to control bacterial growth during the postharvest life of Gerbera, Gypsophila and Matthiola. However, the same 
Table 4. Fresh weight loss and solution uptake of Hydrangea macrophylla cv. Bela cut flowers kept at $20{ }^{\circ} \mathrm{C}$ and $50 \% \mathrm{RH}$ after a flight trip simulation period using two flower preservative solutions. Evaluation was performed considering the number of days to reach $20 \%$ fresh weight loss.

\begin{tabular}{lcc}
\hline Flower preservative solution & Fresh weight loss (days) & Solution uptake $(\mathrm{mL})$ \\
\hline Deionized water & $8.75 \mathrm{a}^{1}$ & $23.96 \mathrm{~b}$ \\
$\mathrm{ClO}_{2}$ & $7.50 \mathrm{ab}$ & $26.56 \mathrm{ab}$ \\
Triton X-100 & $3.83 \mathrm{~b}$ & $31.96 \mathrm{a}$ \\
Triton X-100 $+\mathrm{ClO}_{2}$ & $6.83 \mathrm{ab}$ & $26.44 \mathrm{ab}$ \\
\hline
\end{tabular}

${ }^{1}$ Different letters in a row indicate significant differences according to Tukey's test $(\mathrm{P} \leq 0.05)$.

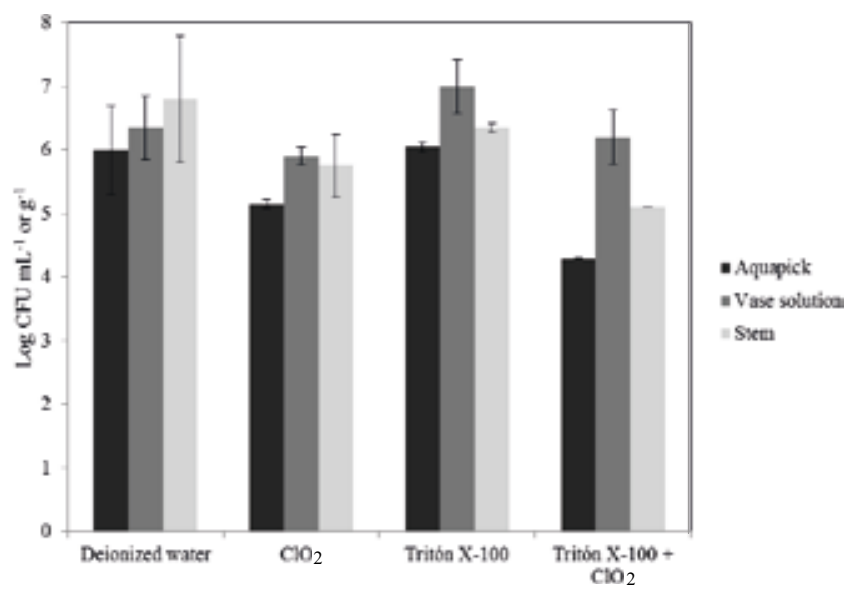

Figure 2. Number of bacteria accumulated in the Aquapick, the vase solution (log UFC mL-1) and the base of the stems $\left(\log \mathrm{UFC}^{-1}\right)$ of Hydrangea macrophylla $\mathrm{cv}$. Bela cut flowers evaluated at the end of vase life.

study observed leaf yellowing and premature flower drop at the concentration of $50 \mu \mathrm{L} \mathrm{L}^{-1}$ applied to others species, such as Alstroemeria and Lilium. Another study described signs of toxicity (brown discoloration at the base) in cut flowers of Oncidium when the stalks were dipped for 5 days into a preservative solution containing $\mathrm{ClO}_{2}$ at a concentration of $50 \mathrm{mg} \mathrm{L}^{-1}$ or higher (Chao et al., 2010). Negative effects have also been observed during the vase life of cut flowers using other biocides, such as aluminum sulfate, sodium benzoate, hydroxyquinoline citrate (HQC), Isocil and Physan-20 (Knee, 2000).

The effect of ethylene on the vase life of hydrangea flower stems has been previously reported only in the fresh stage and has been described to produce bract abscission (Schiappacasse et al., 2014). Considering that this symptom was not observed in this study, the effect of ethylene during postharvest of hydrangea flower stems was negligible.

Preservative solutions negatively affect fresh weight loss but facilitate solution uptake

Triton X-100 is a nonionic detergent used as a surfactant to enhance permeabilization of the cell membrane (Koley and Bard, 2010), suggesting its positive effect on solution uptake observed during postharvest of hydrangea cut flowers (Table 4). Floral stage, among others factors, has been described to influence the effect of flower preservatives in order to obtain a satisfactory water balance (Ahmad et al., 2013). However, the two 
floral stages evaluated in this study showed no statistically significant differences in terms of solution uptake or FWL.

Jowkar et al. (2012) suggested that maximum weight gain and solution uptake are correlated, and subsequently, both are correlated with longer vase life of cut flowers. The present study, however, showed that the slowest fresh weight loss (deionized water) was not related to the highest solution uptake, and vice versa (Table 4). Thus, hydrangeas lost fresh weight slower in deionized water and showed the longest vase life compared to the other treatments. Moreover, dehydration of the bracts was one of the most common symptoms observed during the evaluation of hydrangea, and in many cases, it triggered the end of vase life.

Chlorine dioxide did not show significant differences from the control or from Triton X-100 in terms of solution uptake. A similar observation was suggested by Knee (2000), who observed that some biocides do not increase fresh weight gain, but a number of them actually inhibit it.

\section{$\mathrm{ClO}_{2}$ partially controls bacteria}

Although lower levels of bacteria were counted in the solutions containing $\mathrm{ClO}_{2}$, this substance did not provide very effective control, particularly in the vase solution. van Doorn (1997) described poor efficacy of $\mathrm{ClO}_{2}$ due to its inability to control all vegetative and sporulating bacteria.

Reduction of solution uptake rate due to microbial contamination has been described, suggesting that levels of approximately 5 to $8 \log \mathrm{CFU} \mathrm{mL} \mathrm{mL}^{-1}$ in the vase solution cause water uptake reduction in various flower species (van Doorn, 1997). Moreover, bacteria levels of $11 \log \mathrm{CFU} \mathrm{mL} \mathrm{m}^{-1}$ significantly reduce water uptake in 'Charlotte' roses (Macnish et al., 2008). In this study, the high presence of bacteria in the vase solution of all the treatments evaluated seemed not to affect solution uptake (Table 3) since no relation between this parameter and the accumulation of bacteria was observed.

Bacterial plugging is usually observed in the base of the stems of cut flowers, affecting water uptake and vase life (Ratnayakea et al., 2012). According to the results described in this study, this phenomenon was not observed; despite the high presence of bacteria detected, particularly in the vase solution and the base of the stem by the end of the vase life, water uptake was not reduced. Furthermore, the higher water uptake using Triton X-100 also showed higher bacterial counts (Figure 2). This could be explained by the vascular size of the stem, which is one of the main factors controlling water uptake and vase life in cut flowers (van Doorn, 1997). Thus, previous studies have described that occlusion of xylem is not observed in Hydrangea macrophylla due to protrusions emanating from axial parenchyma cells into xylem vessels through pits (Schweingruber et al., 2011).

Anatomy of Hydrangea macrophylla would explain solution uptake and water loss results

The aesthetic value of the genus Hydrangea comes from its colored bracts, which are foliar organs, as well as petals, but less modified (Esau, 1977). Microscopic observations have confirmed that hydrangea bracts show a high number of stomata, more similar to leaves than petals, which could explain the severe fresh weight loss despite the high solution uptake observed, (Table 4) since the balance between transpiration and water uptake is crucial during the vase life of cut flowers (van Doorn, 1997). Thus, although no stomata were observed on the adaxial surface, abundant stomata were observed on the abaxial side of the bracts (Figure 3 ), reaching values of $37( \pm \mathrm{SE}=4.9$; $\mathrm{n}=5)$ and $27( \pm \mathrm{SE}=2.2 ; \mathrm{n}=4)$ stomata per $\mathrm{mm}^{-2}$ in the fresh and antique stages, respectively. The density of stomata is related to the loss of water by transpiration (Bergmann 2004), as observed by Schroeder and Stimart (2005), who described transpiration through stomata during Antirrhinum majus postharvest, finding between 100 to 200 stomata $\mathrm{mm}^{-2}$ on the abaxial surface of the leaves, ignoring transpiration through 
the petals. The same authors concluded that stomatal density is related not only to transpiration but also to the total number of stomata per flower. Considering the characteristics of the inflorescence of hydrangea, with a high number of bracts per flower stalk, stomata located on the surface of these bracts would allow a high rate of transpiration that correlated with the high water loss observed. Furthermore, Triton-100 has been described as beneficial to maintaining stomatal opening (Jones et al., 1993), therefore, its effect on hydrangea could explain the higher fresh weight loss observed in flowers preserved with this substance (Table 2).

Despite the fact that $\mathrm{ClO}_{2}$ (biocide) partially controlled the presence of microorganisms, and Triton X-100 (surfactant) enhanced solution uptake during postharvest of hydrangea cut flowers, these flower preservatives were not effective at extending vase life after air shipment simulation of this species. Furthermore, due to the large size of the xylem vessels in hydrangea stems, bacterial plugging is not observed during postharvest. On the other hand, the presence of stomata on the bracts seems to be crucial for the dehydration of the inflorescences of hydrangea, a problem that was not solved by the higher solution uptake promoted by Triton X-100.

\section{Acknowledgements}

This work was supported by CONICYT No. 791100024, CONICYT, Government of Chile. The authors would also like to thank Agro Innova Pirque Ltda. for providing the plant material and to Chilfresh Ltda. for providing essential information about air shipment of hydrangeas.

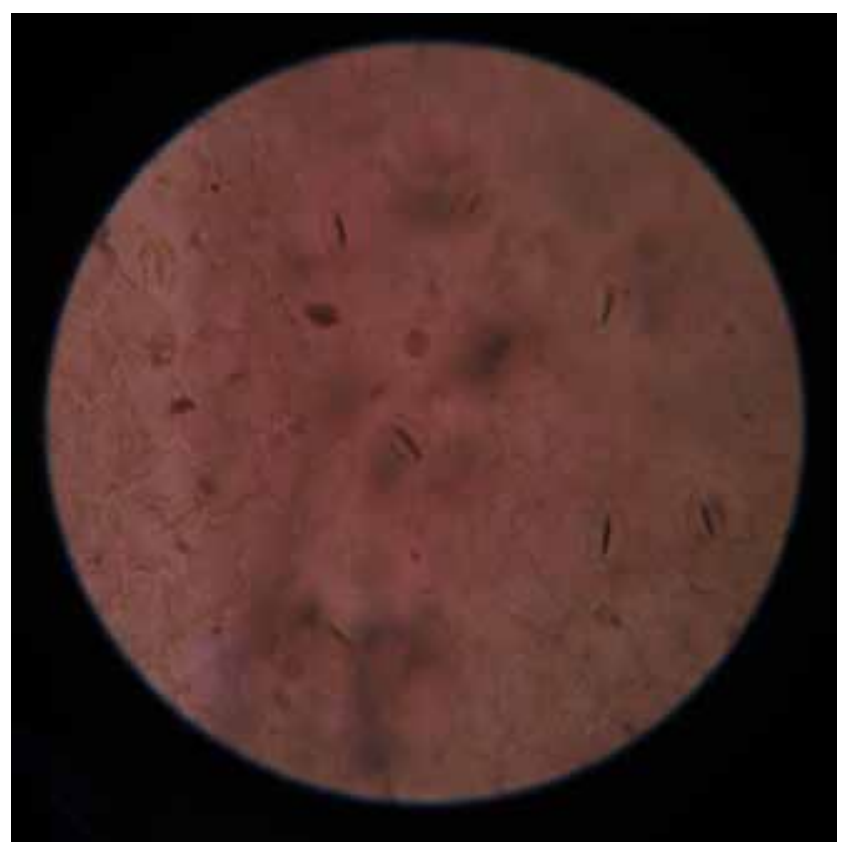

Figure 3. Photograph of stomata observed on the epidermis of the abaxial side of the bracts of Hydrangea macrophylla cv. Bela using a CX21FS1 Olympus stereoscopic microscope at 40X. 


\section{Resumen}

\section{Aros, C. Silva, C. Char, L. Prat y V. Escalona. 2016. Rol de las soluciones preservantes} de flores durante la postcosecha de Hydrangea macrophylla cv. Bela. Cien. Inv. Agr. 43(3):418-428. Hydrangea macrophylla (hortensia) es ampliamente utilizada como planta ornamental y flor de corte debido a su inflorescencia compuesta por brácteas coloreadas. Como flor de corte, las hortensias presentan una vida en postcosecha de hasta un mes a $2^{\circ} \mathrm{C}$ pero poco se conoce sobre su postcosecha durante un envío aéreo. Este estudio tuvo como objetivo evaluar el efecto de Triton X-100 (surfactante) y $\mathrm{ClO}_{2}$ (biocida) durante una simulación de envío aéreo de hortensias cosechadas en dos estados de desarrollo floral: 'fresh' y 'antique'. Durante esta simulación aérea se evaluó vida en florero, pérdida de peso fresco y captura de solución. Además, se realizó un conteo de bacterias y observaciones microscópicas de las brácteas para entender las relaciones hídricas durante la vida en florero. La vida en florero más prolongada se observó en hortensias 'antique' y el control (agua deionizada) fue el mejor tratamiento alcanzando hasta 32,7 días en este estado floral. La pérdida de peso fresco fue más rápida cuando se utilizó Triton X-100 (3,83 días para perder 20\% of peso fresco) en comparación con el agua deionizada (8,75 días). Sin embargo, este preservante floral fue eficiente en promover la captura de solución $(31,96 \mathrm{~mL})$. El taponamiento por bacteria no fue sugerido para esta especie considerando que la alta presencia de microorganismos contabilizados no afectó la captura de solución y la vida en florero. La presencia de estomas en las brácteas parece ser crucial para la deshidratación de la inflorescencia, problema que no fue resuelto por la mayor captura de solución promovido por el Triton X-100. Agua deionizada fue el mejor tratamiento y el efecto de preservantes florales fue insignificante para extender la vida en florero de flores de hortensia.

Palabras clave: $\mathrm{ClO}_{2}$, hortensia, Triton $\mathrm{X}-100$, vida en florero.

\section{References}

Ahmad, I., J. Dole, A. Carlson, and F. Blazich. 2013. Water quality effects on postharvest performance of cut calla, hydrangea, and snapdragon. Scientia Horticulturae 153:26-33.

Bergmann, D.C. 2004. Integrating signals in stomatal development. Current Opinion in Plant Biology 7: 26-32.

Chao, Y.C., S. Hsu, and K. Tzeng. 2010. Bactericidal efficacy of chlorine dioxide against Pectobacterium chrysanthemi and its control for bacterial soft rot on stalk of Oncidium cut flower. Plant Pathology Bulletin 19:127-136.

Esau, K. 1977. Anatomy of Seed Plants. $2^{\text {nd }}$ Edition. John Wiley \& Sons, New York. 576 pp.

Figueroa, I., M. Colinas, J. Mejía, and F. Ramírez. 2005. Postharvest physiological changes in roses of different vase life. Ciencia e Investigación Agraria 32:167-176.
Hajizadeh, H.S., A. Farokhzad, and V.G. Chelan. 2012. Using of preservative solutions to improve postharvest life of Rosa hybrid cv. Black Magic. Journal of Agricultural Technology 8:1801-1810.

Jones, R., M. Serek, and M. Reid. 1993. Pulsing with Triton X-100 improves hydration and vase life of cut sunflowers (Helianthus annuus L.). HortScience 28:1178-1179.

Jowkar, M.M., M. Kafi, A. Khalighi, and N. Hasanzadeh. 2012. Reconsideration in using citric acid as base solution preservative for cut rose flowers. Current research Journal of Biological Sciences 4:427-436.

Kader, A.A. (Technical Editor). 2007. Postharvest Technology of Horticultural Crops. 3rd ed. Agriculture and Natural Resources. Publication 3311. University of California, Davis, CA. 535 pp.

Knee, M. 2000. Selection of biocides for use in floral preservatives. Postharvest Biology and Technology 18:227-234. 
Koermer, G.S., and T.D. Wldman. 2002. Method for extending the life of cut flowers. U.S. Patent 6:440-900.

Koley, D., and A.J. Bard. 2010. Triton X-100 concentration effects on membrane permeability of a single HeLa cell by scanning electrochemical microscopy (SECM). PNAS (107) 39:16783-16787.

Macnish, A., R. Leonard, and T. Nell. 2008. Treatment with chlorine dioxide extends the vase life of selected cut flowers. Postharvest Biology and Technology 50:197-207.

Macnish, A.J., K.L. Morris, A. de Theije, M.G.J. Mensink, H.A.M. Boerrigter, M.S. Reid, C.Z. Jiang, and E.J. Woltering. 2010. Sodium hypochlorite: A promising agent for reducing Botrytis cinerea infection on rose flowers. Postharvest $\mathrm{Bi}$ ology and Technology 58:262-267.

Ratnayakea, K., D.C. Joyce, and R.I. Webb. 2012. A convenient sample preparation protocol for scanning electron microscope examination of xylemoccluding bacterial biofilm on cut flowers and foliage. Scientia Horticulturae 140:12-18.

Sacco, E., M. Savona, M. Antonetti, A. Grassotti, P.L. Pasqualetto, and B. Ruffoni. 2012. In vitro propagation and regeneration of several hydrangea genotypes. Acta Horticulturae 937:565-572.

Seyed, H., A. Farokhzad, and C. Ghasemi. 2012. Using of preservative solutions to improve postharvest life of Rosa Hybrid cv. Black Magic. Journal of Agricultural Technology 8:1801-1810.
Schiappacasse, F., C. Moggia, and R., Contreras. 2014. Studies with long term storage of cut flowers of Hydrangea macrophylla. Idesia 32:71-76.

Schroeder, K.R., and D.P. Stimart. 2005. Comparison of stomatal density and postharvest transpiration between long- and short-lived cut flower genotypes of Antirrhinum majus L. Journal of the American Society for Horticultural Science 130:742-746.

Schweingruber, F.H., A. Börner, and E.D. Schulze. 2011. Atlas of stem anatomy in herbs, shrubs and trees. Volume 1. Springer, Heidelberg, Dordrecht, London, New York. 495 pp.

van Gelderen, C.J., and D.M. van Gelderen. 2004. Encyclopedia of Hydrangeas. Timber Press, Portland, Oregon. 280 pp.

van Doorn, W.G. 1997. Water relations of cut flowers. Horticultural Reviews 18:1-85.

van Doorn, W.G., P. Abadie, and P. Belde. 2001. Alkylethoxylate surfactants for rehydration of roses and Bouvardia flowers. Postharvest Biology and Technology 24:327-333.

van Doorn, W.G., and S.S. Han. 2011. Postharvest quality of cut lily flowers. Postharvest Biology and Technology 62:1-6.

van Meeteren, U., and H. van Gelder. 1999. Effect of time since harvest and handling conditions on rehydration ability of cut chrysanthemum flowers. Postharvest Biology and Technology 16:169-177. 
